\title{
Sustainable Recycling of Insoluble Rust Waste for the Synthesis of Iron-Containing Perovskite-Type Catalysts
}

\author{
Francesca Deganello, ${ }^{*}{ }^{\dagger}$ (i) Manisha Joshi, ${ }^{+\infty}$ Leonarda F. Liotta, ${ }^{\dagger}$ (이 Valeria La Parola, ${ }^{\dagger}$ \\ Giuseppe Marcì, ${ }^{\S \odot}$ and Giuseppe Pantaleo ${ }^{\dagger \odot}$ \\ †Istituto per lo Studio dei Materiali Nanostrutturati, Consiglio Nazionale delle Ricerche, (CNR-ISMN), Via Ugo La Malfa 153, \\ Palermo 90146, Italy \\ Department of Chemistry, Priyadarshini College of Engineering (PCE), Hingna Road, Nagpur 440019, India \\ ${ }^{\S}$ Dipartimento di Energia, Ingegneria dell'informazione e modelli Matematici (DEIM), Università di Palermo, Viale delle Scienze, \\ edificio no. 6, Palermo 90128, Italy
}

Supporting Information

ABSTRACT: Insoluble rust waste from the scraping of rusted iron-containing materials represents a cheap, eco-friendly, and available source of iron. $\mathrm{LaFeO}_{3}$ perovskite-type powders were successfully prepared by solution combustion synthesis using rust waste from an electricity transmission tower manufacturer. Solution combustion synthesis enabled introduction of this insoluble iron precursor directly into the final product, bypassing complex extraction procedures. Catalytic activity in the propylene oxidation of the waste-derived $\mathrm{LaFeO}_{3}$ with stoichiometric $\mathrm{Fe} / \mathrm{La}$ ratio was almost identical to the commercial iron nitrate-derived $\mathrm{LaFeO}_{3}$, thus demonstrating the viability of this recycling solution. The amount of waste iron precursor was varied and its effect on the powder properties was investigated. A lesser stoichiometric amount of precursor produced a $\mathrm{LaFeO}_{3}-\mathrm{La}_{2} \mathrm{O}_{3}$ binary system, whereas a higher stoichiometric amount led to a $\mathrm{LaFeO}_{3}-\mathrm{Fe}_{2} \mathrm{O}_{3}$ binary system. Catalytic activity of iron-rich compositions in the propylene oxidation was only slightly lower than the stoichiometric one, whereas iron-poor compositions were much less active. This eco-friendly methodology can be easily extended to other iron perovskites with different chemical compositions and to other iron-containing compounds.

\section{INTRODUCTION}

The iron element is present in most of the perovskite-type catalyst formulations for application in pollution control, solar conversion, oxygen separation, electrochemical production, and storage of energy and sensoristics. ${ }^{1-5}$ The presence of iron at $\mathrm{B}$-site of the $\mathrm{ABO}_{3}$ perovskite structure ensures very good reactivity toward oxygen and oxygenated compounds. Iron perovskites are usually prepared from a commercial iron nitrate precursor, ${ }^{2,3}$ but sustainable methodologies to obtain ironcontaining catalysts from waste-derived iron-rich sources are highly desirable, according to the concepts of circular economy promoted by the European Commission. ${ }^{6}$ Most of the experimental procedures proposed in the literature for iron waste recycling deal with the synthesis of other materials and not perovskites. For example, waste ferrous sulfate from titanium dioxide industry, ${ }^{7}$ heavy tonnage iron-removal sludge waste, ${ }^{8}$ oily cold rolling mill sludge, and ashes of scum from anaerobic treatment of municipal sewage ${ }^{9}$ have been used as inorganic precursors for preparing iron-based pigments or hematite nanoparticles. Recently, rusted iron coil and stainless steel wires have also been used for preparing hematite film with

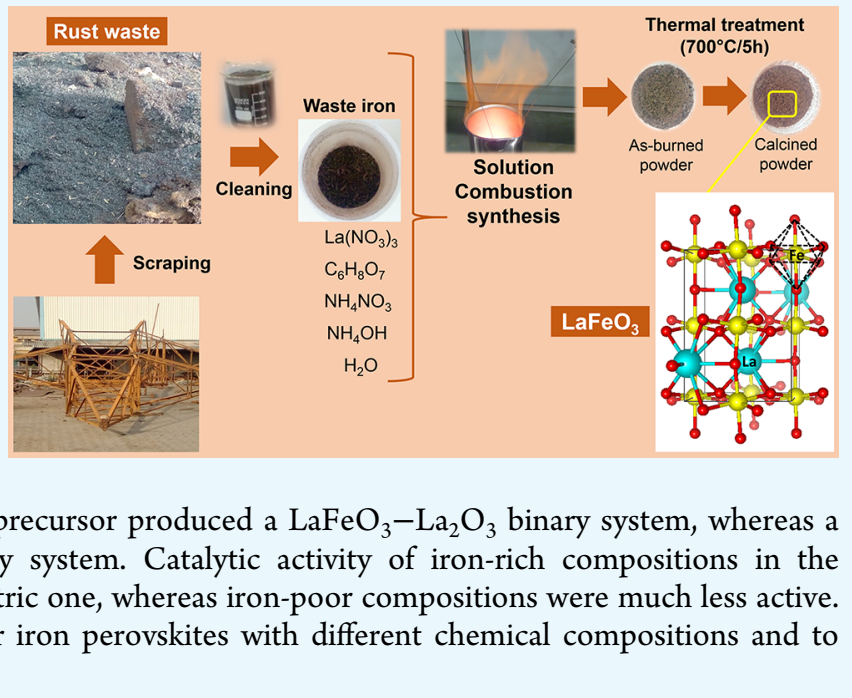

water oxidation and oxygen evolution activity. ${ }^{10}$ Apparently, only in the works by Pullar et al. ${ }^{11}$ and Dufour et al. ${ }^{12}$ a perovskite-type barium hexaferrite magnetic material has been produced from dried steel wiredrawing sludge waste as iron source. Waste iron, which is produced from the scraping of rusted iron-containing materials, can also be used as an iron source for the synthesis of nanomaterials with high catalytic activity and selectivity ${ }^{13-15}$ and represents a cheap, ecofriendly, and inexhaustible source of iron. In fact, if rust has already been formed, rust scraping is necessary to remove rust from the surface, preventing the iron objects from further damage. This rust must be disposed of as waste or dismissed as scrap iron at very low rates.

The aim of this work is to evaluate the possibility of using rust waste from scraping as a source of iron for the synthesis of an iron perovskite such as $\mathrm{LaFeO}_{3}$ nanomaterial. This ironbased compound was selected as a proof-of-concept material

Received: December 15, 2018

Accepted: January 30, 2019

Published: April 18, 2019 
for three main reasons: (i) with respect to other multicomponent and doped perovskites, the simplicity of this chemical composition limits any possible segregation and avoids useless complexity of the interpretation of the results, in line with the literature; ${ }^{16,17}$ (ii) the preparation of a perovskite compound instead of a simple iron-based oxide expands the applicability of the synthesis to a wider class of iron-based compounds and to a variety of technological uses; and (iii) $\mathrm{LaFeO}_{3}$ itself shows a discrete catalytic activity as an oxidation catalyst for carbon monoxide, nitrous oxide, methane, soot, and volatile organic compounds (VOCs). ${ }^{18,19}$

For the preparation of $\mathrm{LaFeO}_{3}$ powders, we chose the solution combustion synthesis, an easy and convenient solution-based method for the preparation of mixed oxides and in particular perovskite-type compounds. ${ }^{20}$ The core of this methodology is a self-sustained redox reaction between a fuel and an oxidant in the presence of metal precursors. The combustion process is a very fast reaction (about 10-20 s), which transforms fuel and oxidant into gases, leaving the desired powdered product. A further thermal treatment may be necessary, depending on the experimental conditions used and the chemical composition. ${ }^{20}$ Both sol-gel chemistry and propellant chemistry play an important role in the solution combustion synthesis. The formation of a gel network before the self-sustained combustion is an essential part of the synthesis since all of the components of the combustion mixture are "fixed" in the network. Therefore, if they interacted well in the network, the right products will form during the combustion process or the subsequent thermal treatment. ${ }^{20}$ This methodology allows the direct use of solid waste precursors, bypassing any complex extraction procedure. ${ }^{20}$ In fact, most of the procedures proposed in the literature to recycle the waste iron make use of extraction by strong acids to dissolve the solid iron precursor. ${ }^{9,14,15,21}$ For the sake of comparison, reference $\mathrm{LaFeO}_{3}$ powder was also prepared by solution combustion synthesis using a commercial iron nitrate precursor. Several characterization techniques were used in this work to understand in detail the effect of the waste iron precursor amount on the chemical-physical properties of the obtained $\mathrm{LaFeO}_{3}$ powders and to compare the waste iron precursor with the commercial one. The performance of all of the $\mathrm{LaFeO}_{3}$ powders was evaluated by testing the activity and selectivity in the oxidation of propylene, a VOC air pollutant emitted from car exhaust gases. Propylene is usually fully oxidized to $\mathrm{CO}_{2}$ by using heterogeneous catalysts based on mixed oxides and metal nanoparticles. ${ }^{22}$ Recently, it has been found that $\mathrm{LaFeO}_{3}$ is able to catalyze propylene oxidation. ${ }^{23}$

\section{RESULTS AND DISCUSSION}

Features of the Waste Iron Precursor. Qualitative analysis of X-ray diffraction patterns in Figure 1 indicated that the as-received rust waste (red line) was composed of metallic iron and iron oxides. This is not surprising since the scraping treatment is known to take out the rusted layer together with the $\mathrm{Fe}_{3} \mathrm{O}_{4}$ and metallic iron underlying layers. It was not possible to discriminate the type of iron oxides $\left(\mathrm{FeO}, \mathrm{Fe}_{3} \mathrm{O}_{4}\right.$, $\mathrm{Fe}_{2} \mathrm{O}_{3}$, or hydrated $\mathrm{Fe}_{2} \mathrm{O}_{3}$ ) from the XRD pattern analysis because of the low XRD signal of such a multicomponent material formed by powder and chippings (Figure 1).

Fourier transform infrared (FT-IR) results in Figure S1 indicated that hydrated $\mathrm{Fe}_{2} \mathrm{O}_{3}$ and $\mathrm{Fe}_{3} \mathrm{O}_{4}$ compounds were the main constituents of the first few micrometers of the asreceived rust waste surface. According to X-ray photoelectron

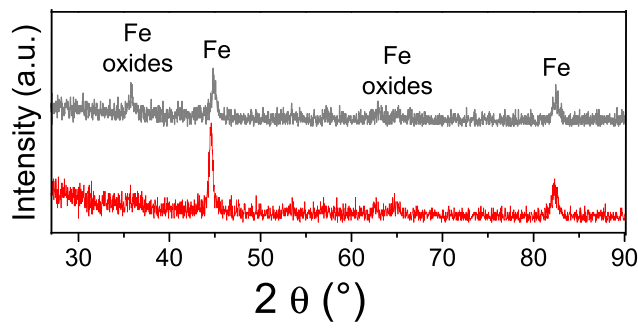

Figure 1. XRD pattern of the rust waste before (red line) and after (gray line) the cleaning treatment.

spectroscopy (XPS) analysis, the surface of the as-received rust waste contained only iron from hematite particles and produced a neat survey spectrum without any contaminant (Figure S2). Scanning electron microscopy (SEM) images of the as-received rust waste (Figure 2, in the red box) confirmed the presence of zones with different features $(A-C)$ due to the multicomponent nature of this solid waste.

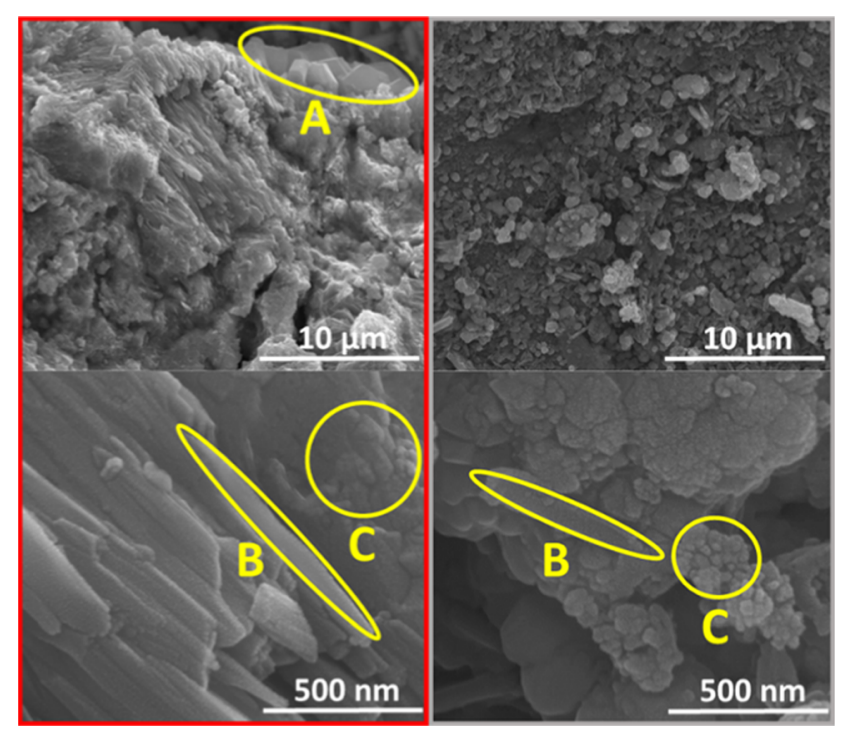

Figure 2. SEM images at two different enlargements of the as-received rust waste (left column, in the red box) and of the washed one (right column, in the gray box). "A" indicates the metallic iron cubes, "B" indicates the $\mathrm{Fe}_{3} \mathrm{O}_{4}$ elongated crystals, and " $\mathrm{C}$ " indicates the roundish (hydrated) hematite particles.

According to energy-dispersive X-ray (EDX) analysis, the micrometric cubes visible in the as-received rust waste (Figure 2 , top left, feature $\mathrm{A}$ ), with a $\mathrm{Fe} / \mathrm{O}$ atomic ratio of 70 , are mainly ascribable to metallic iron, present in the rust waste as a result of the scraping, considering the larger amount of iron compared to oxygen. The elongated crystals (Figure 3, bottom left, feature B), with a $\mathrm{Fe} / \mathrm{O}$ atomic ratio of $43: 57$, were clearly associated with magnetite $(\mathrm{Fe} / \mathrm{O}=0.75)$. The agglomerated roundish particles (Figure 3, bottom left, feature $\mathrm{C}$ ), with a $\mathrm{Fe}$ / $\mathrm{O}$ atomic ratio of 57:43 (1.32), indicated a major presence of (hydrated) hematite crystals $(\mathrm{Fe} / \mathrm{O}=1.5)$. Therefore, the asreceived rust waste was composed of an inner layer of metallic iron, a middle layer of $\mathrm{Fe}_{3} \mathrm{O}_{4}$, and a surface layer of $\mathrm{FeOOH}$, in agreement with the literature. ${ }^{24}$

After the cleaning procedure, the only apparent effect to the XRD pattern is a decreased percentage of metallic iron compared to the percentage of iron oxides (Figure 1). XPS analysis of the surface did not detect any visible change in the 

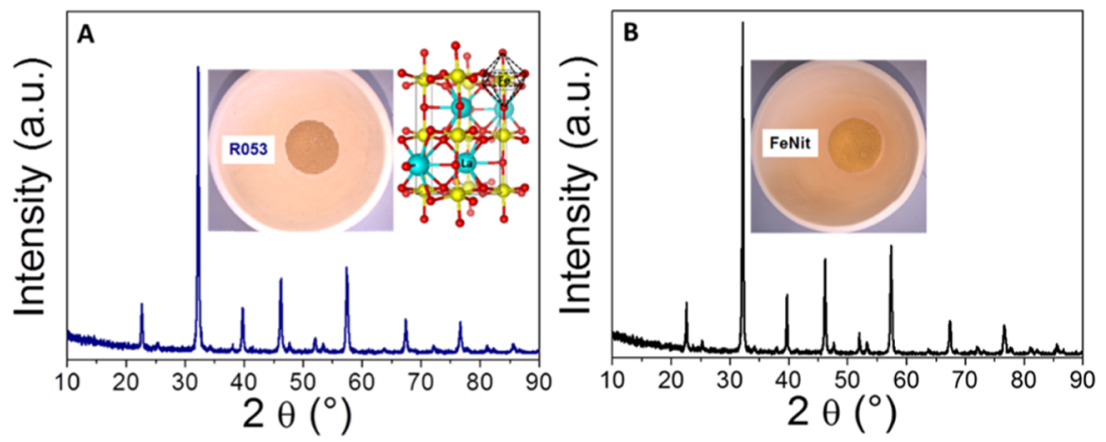

Figure 3. XRD patterns of the rust waste-derived sample (A) and the reference sample (B). The image of the structure represents the unit cell of the $\mathrm{LaFeO}_{3}$ perovskite-type compounds. All of the pictures were taken by the authors.

Fe $2 p$ peak (Figure S3). SEM-EDX images of the rust wastes after the cleaning treatment (Figure 2, in the gray box) indicated that the agglomerated roundish particles represent the majority of the powder (Figure 2, bottom right, feature $\mathrm{C}$ ), whereas some short crystals of $\mathrm{Fe}_{3} \mathrm{O}_{4}$ were still visible (Figure 2 , bottom right, feature $\mathrm{B}$ ), in agreement with the XRD results. Therefore, it can be concluded that the cleaning treatment has essentially the effect of eliminating any suspended impurity, decreasing the metallic iron percentage and slightly increasing the hydrated hematite surface layer present on the solid rust waste.

Waste Iron Precursor or Commercial Iron Precursor? A Comparison. The combustion process, the main chemicalphysical properties, and the catalytic activity in the propylene oxidation of $\mathrm{LaFeO}_{3}$ prepared from the waste iron precursor (R053) were compared to those of a $\mathrm{LaFeO}_{3}$ prepared from commercial iron nitrate precursor (FeNit), to investigate the effect of the iron precursor type on the material properties. The stoichiometric amount of waste iron precursor was determined experimentally according to a procedure described in the Supporting Information (p S17).

Temperature/time profiles of R053 and FeNit denoted a multistep nature of the process, highlighted by the presence of more than one temperature/time peak in each profile and/or by the presence of asterisks, each of them corresponding to a stimulation of the combustion process through manual mixing (Figure S4). This is mainly ascribable to the high $\Phi$ (reducerto-oxidizer ratio) value used for the synthesis, since overstoichiometric $\Phi$ values are known to decrease the intensity of the combustion process and may cause local interruption of the combustion wave. ${ }^{20}$ The multistep nature of the combustion process, other than representing an obstacle to the synthesis, can be considered as an advantage for mass production of the powdered product. In fact, a combustion process with lower intensity allows increasing the amount of powder produced at the same level of risk. ${ }^{20}$ By comparing the profiles in Figure S4, it is worth noting that the maximum temperature registered for $\mathrm{R} 053$ is $100{ }^{\circ} \mathrm{C}$ higher than that for FeNit. Besides the difficulty in registering a direct measurement of the temperature for multistep combustion processes (comment to Figure S4), the combustion of R053 was more intense than for FeNit also at visual perception. This difference was ascribed to an effect of the iron precursor type. In fact, insoluble particles of iron precursor were still suspended in the gel mass of R053 before combustion, and their fast oxidation might be responsible for the higher intensity of the combustion process in this sample. It can be concluded that there was no influence of the iron precursor type on the multistep nature of the combustion process, but the local combustion waves were slightly more intense in the case of the waste-derived powder.

The perovskite-type $\mathrm{LaFeO}_{3}$ structure was already formed in both the as-burned powders (Figure S5). Traces of lanthanum oxides and iron oxides were present in the XRD patterns of both the as-burned powders, as shown in Figure S5, where only the most intense peaks of these secondary phases were indicated. This is not surprising since perovskite phase is usually formed from the respective oxides. No metallic iron was left unreacted in R053. We assumed that iron incorporation into the $\mathrm{LaFeO}_{3}$ perovskite structure was strongly promoted by the interaction of metallic iron/iron oxides with citric acid through chemisorption and by the intense redox reaction during combustion. After calcination at $700{ }^{\circ} \mathrm{C}$, the perovskite structure was fully formed (Figure 3 ).

Cell volume of the FeNit reference, as determined by Rietveld refinement, was $242.85 \pm 0.04 \AA^{3}$, in agreement with the literature. ${ }^{23}$ Cell volume of the waste-derived $\mathrm{LaFeO}_{3}$ was $243.01 \pm 0.05 \AA^{3}$, slightly larger, probably due to a higher oxygen defectivity provoked by a size/strain effect. In fact, the crystal size of the perovskite phase in R053 was $50 \mathrm{~nm}$, slightly smaller than for the reference sample $(63 \mathrm{~nm})$. In addition, microstrain was larger for the waste-derived sample $(0.182$ compared to 0.071$)$, indicating a larger perturbation of the powder structure/microstructure. Looking at the structural properties of the perovskite powders, the waste iron was comparable to the commercial iron nitrate as iron precursor for the solution combustion synthesis of $\mathrm{LaFeO}_{3}$ nanopowders.

From the SEM images of Figure 4, it appears evident that the type of iron precursor influenced the microstructure and morphology of these samples.

In both cases, the powders consisted of particles with size ranging between ca. 35 and $140 \mathrm{~nm}$, considering that the largest ones were only observed in the case of FeNit sample. This is in good agreement with the crystal size values calculated from XRD analysis. Moreover, the particles of the sample obtained by waste iron (R053) had a prevalently roundish shape, whereas those of the reference powder (FeNit), obtained from the commercial iron nitrate, were less regular and in some cases appear elongated or fused with each other. After calcination at $1000{ }^{\circ} \mathrm{C}$, grain size increased for both samples, although the observed differences were maintained (Figure S6), in agreement with crystal size values obtained by XRD analysis. This important result shows for the first time a microstructural templating effect of the inorganic precursor used in the solution combustion synthesis. It is worth noting that to date, the main microstructural templating effect has been attributed to the fuel or an external template. ${ }^{20}$ 


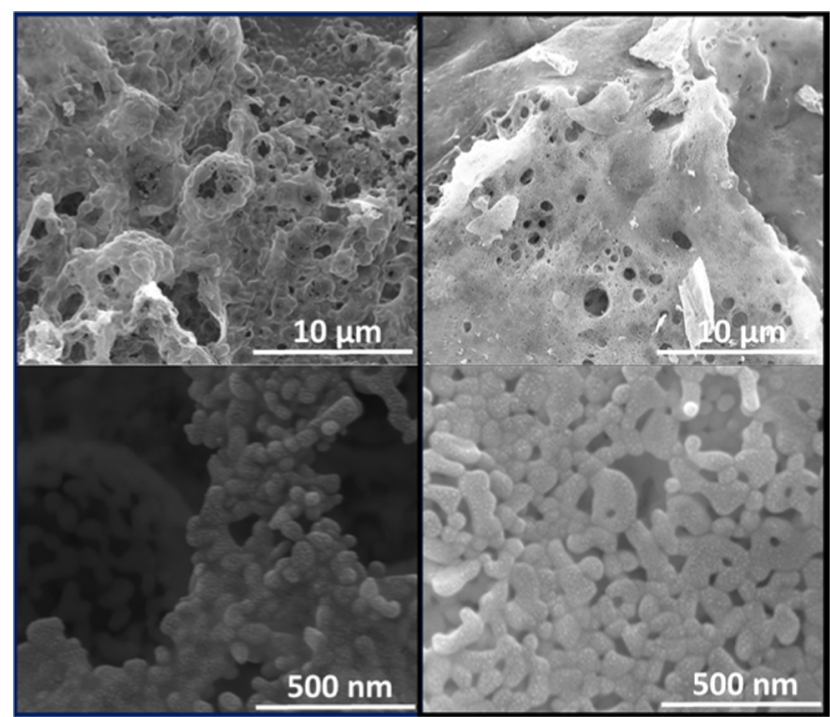

Figure 4. SEM images at two different enlargements, of the wastederived sample (left column, in the blue box) in comparison to the reference sample (right column, in the black box).

EDX analysis performed during SEM observations registered slightly larger $\mathrm{Fe} / \mathrm{La}$ ratios than the nominal ones for both the samples (1.3 for R053 and 1.2 for FeNit), whereas microwave plasma atomic emission spectroscopy (MP-AES) confirmed the stoichiometric nature of the $\mathrm{Fe} / \mathrm{La}$ ratio in FeNit and R053.

Fe depletion/La enrichment on the surface was observed by XPS in both samples (Fe/La was 0.5 for R053 and 0.6 for FeNit), in agreement with the literature. ${ }^{25}$ The downshift of $\mathrm{Fe}$ 2p peaks from 711.0 to $710.7 \mathrm{eV}$ (FeNit) and $710.5 \mathrm{eV}$ (R053) confirmed the incorporation of iron in the perovskite structure of both R053 and FeNit samples (Figure 5). Indeed, lanthanum position (ca. $834 \mathrm{eV}$ ) in R053 and FeNit was very similar (Figure 5) and typical of perovskite-type materials. $^{23,26}$

Oxygen peaks of the perovskite-type powders contained components due to perovskites lattice (subsurface) at ca. 529 $\mathrm{eV}$ and to surface oxygen at about $531 \mathrm{eV}$, generated by $\mathrm{OH}$

\section{1s}

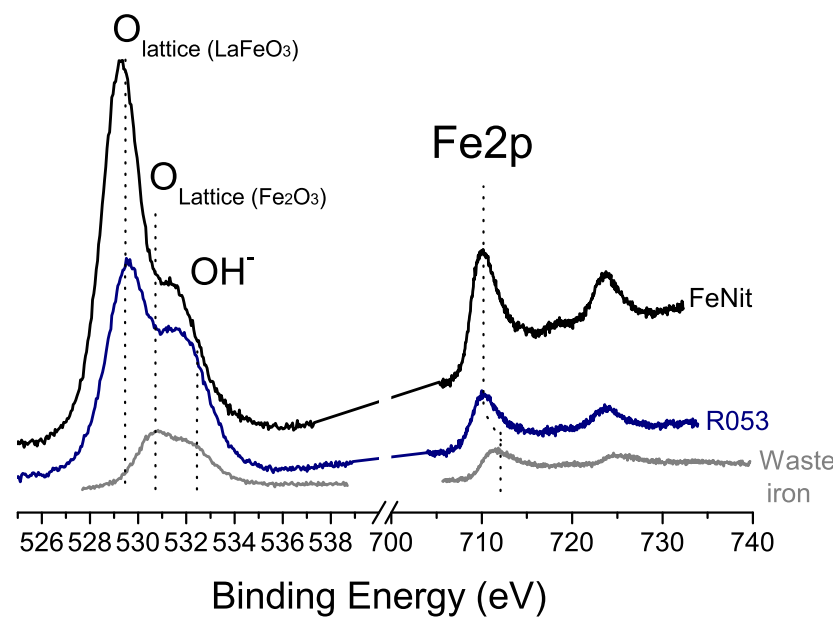

Figure 5. O 1s and Fe 2p XPS images of waste iron in comparison to those of R053 and FeNit. terminal groups. The $\mathrm{OH}$ contribution in $\mathrm{R} 053$ was much larger than that in FeNit, in agreement with the smaller crystal size, smaller grain size, and slightly larger surface area.

Reduction profiles of R053 and FeNit are displayed in Figure S7a, and the hydrogen consumption values are summarized in Table S1. Both the temperature-programmed reduction (TPR) curves showed two main reduction regions. The first one was registered below $800{ }^{\circ} \mathrm{C}$ with small hydrogen consumption, whereas the main reduction process started above $800{ }^{\circ} \mathrm{C}$. The TPR profiles of Figure $\mathrm{S7a}$ are in agreement with the literature, according to which the reduction of $\mathrm{LaFeO}_{3}$ takes place in two steps and involves the $\mathrm{Fe}^{3+}$ to $\mathrm{Fe}^{2+}$ reduction at lower temperatures and the $\mathrm{Fe}^{2+}$ to $\mathrm{Fe}^{0}$ reduction at higher temperatures. ${ }^{18}$ However, in both the samples, the main reduction peak did not reach completeness even at $1000{ }^{\circ} \mathrm{C}$, the maximum temperature reached in our experimental conditions (Figure S7a). In fact, the experimental $\mathrm{H}_{2}$ consumption below $800^{\circ} \mathrm{C}$ was significantly lower than the theoretical $\mathrm{H}_{2}$ required for the total $\mathrm{Fe}^{3+}$ to $\mathrm{Fe}^{2+}$ reduction ( 0.15 or 0.32 vs $2.06 \mathrm{mmol} / \mathrm{g}$ ), indicating only a partial reduction of $\mathrm{Fe}^{3+}$ to $\mathrm{Fe}^{2+}$. This is in line with the phase composition obtained by Rietveld analysis of the XRD patterns after the TPR experiment (Figure S7b). The reduction feature above $800{ }^{\circ} \mathrm{C}$, corresponding to $2.04 \mathrm{mmol} \mathrm{H}_{2} / \mathrm{g}$, well accounted for the complete reduction to $\mathrm{Fe}^{2+}$ and for the beginning of $\mathrm{Fe}^{2+}$ to $\mathrm{Fe}^{0}$, with the theoretical $\mathrm{H}_{2}$ consumption $\mathrm{Fe}^{2+}$ to $\mathrm{Fe}^{0}$ equal to $4.12 \mathrm{mmol} / \mathrm{g}$ (Table S1). Although TPR results confirmed high similarity of R053 with FeNit, the same results pointed out to a slight effect of the waste iron precursor on the reducibility of $\mathrm{Fe}^{3+}$ cations present in the perovskitetype powder.

In Figure S8, the $\mathrm{N}_{2}$ adsorption/desorption isotherms (a) and cumulative pore volume vs average pore size distribution (b) for R053 and FeNit are displayed, respectively. Both the powders had low porosity, typical of $\mathrm{LaFeO}_{3}$ calcined at 700 ${ }^{\circ} \mathrm{C}$ with a type II form of adsorption/desorption isotherms, ${ }^{27}$ exhibiting a very small hysteresis only at high $P / P_{0}$ pressure values $(0.9-1.0)$, likely due to the contribution of interparticle voids. The broad pore size distribution curve and the very low pore volume registered (see Figure S8b and Table S2) suggest the presence of few pores with not well-defined shape. With respect to the reference sample prepared by iron nitrate (FeNit), a slightly larger Brunauer-Emmett-Teller value was registered for R053, 14.5 vs $10.3 \mathrm{~m}^{2} / \mathrm{g}$ (Table S2).

Looking at Figure 6, FeNit and R053 showed almost identical $\mathrm{C}_{3} \mathrm{H}_{6}$ conversion curves.

The reaction starts above $250{ }^{\circ} \mathrm{C}, 50 \%$ of propylene conversion being reached at around $350{ }^{\circ} \mathrm{C}$ and full conversion at $500{ }^{\circ} \mathrm{C}$. In the entire range of temperature, for both catalysts, the oxidation of $\mathrm{C}_{3} \mathrm{H}_{6}$ was complete to $\mathrm{CO}_{2}$ without $\mathrm{CO}$ formation. The data reported so far is in agreement with similar results reported in the literature for $\mathrm{LaFeO}_{3}$ perovskites tested in the same reaction at the same space velocity. ${ }^{23}$ Apparently, the small enhancement in textural and microstructural properties and in $\mathrm{Fe}^{3+}$ reducibility observed for the waste-derived sample did not affect the propylene oxidation.

Effect of the Waste Iron Precursor Amount on the Properties of the Waste-Derived Material. The waste iron content was varied from 0.46 to $1.18 \mathrm{~g}$. Its effect on the combustion process and on the powder properties and catalytic performance was investigated over this range.

For any waste iron content, the temperature-time profile of the rust waste-derived samples resembled that of R053. In 


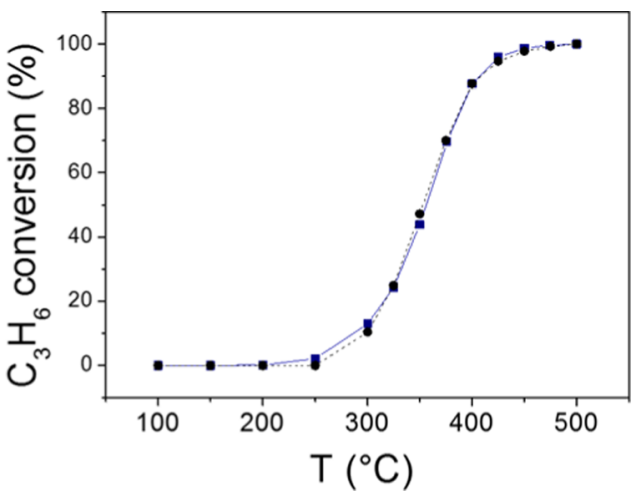

Figure 6. Conversion curves for the propylene oxidation on the waste-derived sample (blue squares, solid line) and the reference sample (black circles, dashed line).

Figure S9, the temperature/time profiles of an iron-poor sample (R049) and an iron-rich sample (R118) are shown. As for R053 (Figure S4), both the profiles were characterized by a localized ignition of the gel mass, although the temperaturetime profile reported for R118 showed much more attenuation of the combustion wave than that reported for R049 (Figure S9).

Figure 7 shows the XRD patterns of a representative ironpoor sample (R046) and iron-rich sample (R118) after different thermal treatments.

$\mathrm{LaFeO}_{3}$ perovskite phase was present in all of the XRD patterns. No secondary phases were visible in the iron-poor sample, whereas $\mathrm{Fe}_{2} \mathrm{O}_{3}$ secondary phase was clearly visible in the iron-rich sample. However, a further thermal treatment at $1000{ }^{\circ} \mathrm{C} / 5 \mathrm{~h}$ evidenced the presence of a secondary phase also in the iron-poor sample (Figure 7). This secondary phase was identified as a La-containing compound that in the freshly calcined powder was $\mathrm{La}_{2} \mathrm{O}_{3}$, although it became $\mathrm{La}(\mathrm{OH})_{3}$ upon hydration by air humidity when the powder was gently ground in an agate mortar for $1 \mathrm{~min}$. Table S3 contains all of the structural and microstructural data obtained from the Rietveld analysis. The type/amount of segregated phases was found to be clearly dependent on the amount of waste iron used in the synthesis (e.g., by the $\mathrm{Fe} / \mathrm{La}$ ratio): $\mathrm{La}(\mathrm{OH})_{3}$ segregation decreased until waste iron reached 0.53 and $\mathrm{Fe}_{2} \mathrm{O}_{3}$ segregation increased for waste iron values from 0.54 to 1.18 . This is better visualized in Figure 8, showing a volcano trend of the perovskite phase weight percentage in the samples calcined at $1000{ }^{\circ} \mathrm{C} / 5 \mathrm{~h}$ as a function of the amount of waste iron used in the synthesis.

It is assumed that a La-containing secondary phase was already present as amorphous, although $\mathrm{La}_{2} \mathrm{O}_{3}$ or $\mathrm{La}(\mathrm{OH})_{3}$ was not detectable in the XRD patterns of the iron-poor sample calcined at $700{ }^{\circ} \mathrm{C}$.

$\mathrm{Fe} / \mathrm{La}$ molar ratio determined by MP-AES increased linearly from 0.87 , for the iron-poor $\mathrm{R} 046$, to 2.24 , for the iron-rich sample R118 (Figure 9).

This trend is in accordance with the amount of waste iron precursor and with the consequent lanthanum oxide or iron oxide segregation. Similarly, the Fe/La ratio calculated by XPS measurements changed with the waste iron content, but a $\mathrm{Fe}$ depletion (La enrichment) on the surface was observed (Figure 9), as already noted for R053. Two oxygen components were still visible in the oxygen $\mathrm{O} 1 \mathrm{~s}$ spectra of the iron-poor and iron-rich samples (Figure 10 and Table S4), as already noted for R053.

The variation of the relative percentage of these two components and their position may be partially correlated with the formation of segregated $\mathrm{Fe}_{2} \mathrm{O}_{3}(\mathrm{O}$ 1s at ca. $530 \mathrm{eV}$ ) or $\mathrm{La}_{2} \mathrm{O}_{3}$ (whose $\mathrm{O} 1 \mathrm{~s}$ ranges between 528.5 and $530.5 \mathrm{eV}^{28}$ ), in agreement with the XRD results of Figure 7 and Table S3. Of
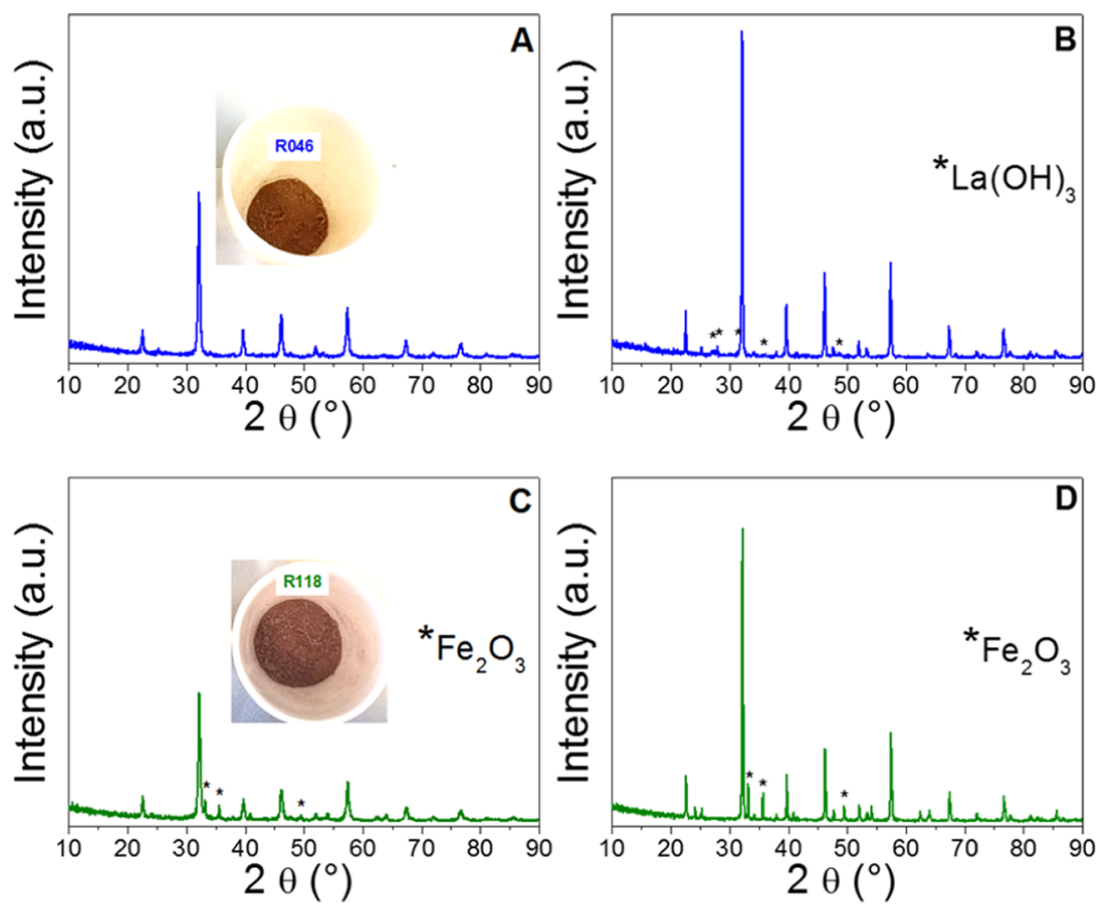

Figure 7. XRD patterns of R046, a representative iron-poor waste-derived sample (A, B), and of R118, a representative iron-rich waste-derived sample $(\mathrm{C}, \mathrm{D})$ after calcination at $700{ }^{\circ} \mathrm{C} / 5 \mathrm{~h}(\mathrm{~A}, \mathrm{C})$ and after further thermal crystallization at $1000{ }^{\circ} \mathrm{C} / 5 \mathrm{~h}(\mathrm{~B}, \mathrm{D})$. All of the pictures were taken by the authors. 


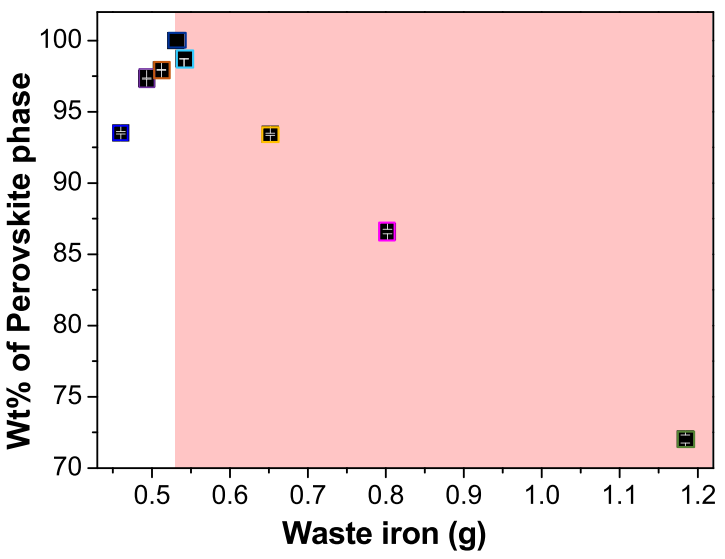

Figure 8. wt \% perovskite phase after thermal treatment at $1000{ }^{\circ} \mathrm{C}$ (with standard deviation calculated from Rietveld refinement) as a function of the waste iron amount. The white zone corresponds to the segregation of the La-containing phase and the pink zone corresponds to the segregation of the $\mathrm{Fe}$-containing phase. Standard deviation is indicated in white inside each square.

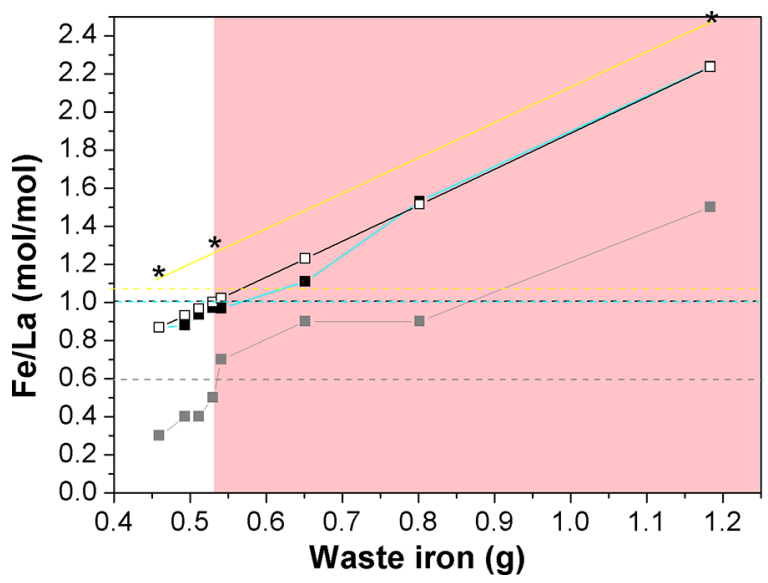

Figure 9. Trend of the $\mathrm{Fe} / \mathrm{La}$ molar ratio with increasing waste iron content for all of the rust waste-derived samples: $\mathrm{Fe} / \mathrm{La}$ obtained from EDX is indicated by black stars and yellow solid line; nominal $\mathrm{Fe} / \mathrm{La}$ by white squares and a black solid line; Fe/La obtained from MP-AES by black squares and cyan solid line; $\mathrm{Fe} / \mathrm{La}$ obtained from XPS by gray squares and gray solid line. The corresponding $\mathrm{Fe} / \mathrm{La}$ ratio of the FeNit reference for each characterization technique is indicated by horizontal dashed lines of the respective color.

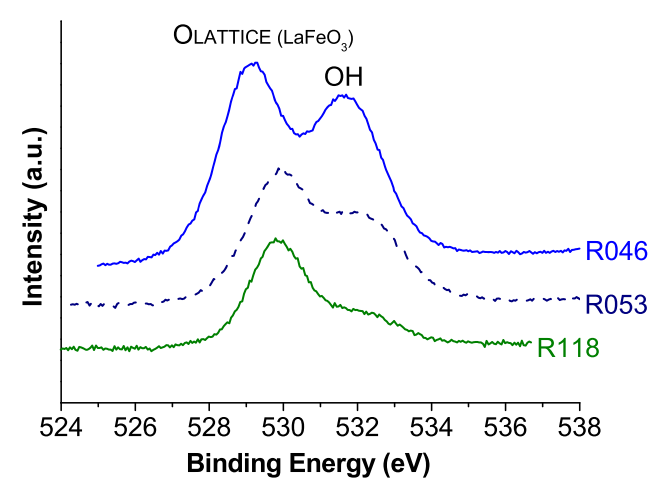

Figure 10. O 1s XPS images of iron-poor (R046) and iron-rich (R118) rust waste-derived powders calcined at $700{ }^{\circ} \mathrm{C} / 5 \mathrm{~h}$ in comparison with R053, with stoichiometric $\mathrm{Fe} / \mathrm{La}$ molar ratio. course, this may affect the catalytic properties of the powder. In fact, it has been found in the literature that understoichiometric $\mathrm{LaFeO}_{3}$ perovskites on the A-site have better catalytic oxidation performance due to the decrease of $\mathrm{La}_{2} \mathrm{O}_{3}$ on the surface and correspondently higher amount of catalytically active iron on the surface. ${ }^{23}$

In Figure 11a, the TPR profiles of two representative wastederived samples with low and high waste iron content are presented in comparison with the R053 sample.

With respect to $\mathrm{R} 053$, much more intense reduction peaks were visible in the TPR profile between 300 and $800{ }^{\circ} \mathrm{C}$, with hydrogen consumption ranging from 0.74 to $4.91 \mathrm{mmol} / \mathrm{g}$ (Figures $10 \mathrm{~b}$ and $11 \mathrm{a}$ ). Massive reduction at such low temperatures observed for R118 (and for the other iron-rich samples) was associated with the complete reduction of $\mathrm{Fe}^{3+}$ to $\mathrm{Fe}^{2+}$ as well as to the partial reduction of $\mathrm{Fe}^{2+}$ to $\mathrm{Fe}^{0}$ in segregated $\mathrm{Fe}_{2} \mathrm{O}_{3} \cdot{ }^{29,30}$ Effectively, the amount of hydrogen consumed below $800{ }^{\circ} \mathrm{C}$ increased as the amount of segregated $\mathrm{Fe}_{2} \mathrm{O}_{3}$ detected by XRD from $\mathrm{R} 053$ (no $\mathrm{Fe}_{2} \mathrm{O}_{3}$ segregated) to $\mathrm{R} 118$ (28 wt $\% \mathrm{Fe}_{2} \mathrm{O}_{3}$ segregated) (Figure 11b). On the contrary, the amount of hydrogen consumed above $800{ }^{\circ} \mathrm{C}$ remained more or less constant (Figure 11b). It is likely that, at low temperature, complete reduction of $\mathrm{Fe}_{2} \mathrm{O}_{3}$ occurs and the metallic iron formed may promote partial reduction of the $\mathrm{LaFeO}_{3}$ (see also Figure S10 and relative comment). Such hypothesis was further confirmed by the almost negligible reduction detected for $\mathrm{R} 118$ above $875{ }^{\circ} \mathrm{C}$ (0.82 vs 2.04 $\mathrm{mmol} / \mathrm{g}$ for FeNit). The presence of a discrete TPR peak in the $100-800{ }^{\circ} \mathrm{C}$ range in the iron-poor R046 might be related to the activation of $\mathrm{H}_{2}$ onto surface oxygen of $\mathrm{La}_{2} \mathrm{O}_{3}$ particles forming $\mathrm{La}(\mathrm{OH})_{3}{ }^{31}$ The possibility that the peaks in the 250$800{ }^{\circ} \mathrm{C}$ range were due to some $\mathrm{Fe}_{2} \mathrm{O}_{3}$ present on the $\mathrm{R} 046$ surface can be ruled out, since XPS and MP-AES results claim for $\mathrm{R} 46$ an under-stoichiometric $\mathrm{Fe} / \mathrm{La}$ ratio. The difference in redox behavior among the iron-poor and iron-rich samples might partially affect as well their redox interaction with propylene.

Table S5 contains all of the textural data for some of the waste-derived samples investigated. From the analysis of data listed in Table S5, it emerges that the morphological features of the prepared samples are similar, without any significant effect played by the amount of waste iron. The surface area values were about $14 \mathrm{~m}^{2} / \mathrm{g}$ and comparable to or somehow higher than the values generally reported in the literature for $\mathrm{LaFeO}_{3}$ perovskites, ${ }^{2,28,30,32}$ as already observed for R053.

In Figure 12, SEM images of an iron-poor powder (R046) are compared to those of an iron-rich one (R118).

Morphology was clearly different in the two samples, both after thermal treatment at 700 and $1000{ }^{\circ} \mathrm{C}$. Roundish particles were visible in the iron-poor powder, whereas in the iron-rich powder, hexagonal particles were evident, particularly after thermal treatment at $1000{ }^{\circ} \mathrm{C}$. SEM image of R118 sample calcined at $700{ }^{\circ} \mathrm{C}$ resembles very much the SEM image of the waste iron at the same enlargement (Figures 2 and 12), whereas R046 (Figure 12A,C) has different morphology and slightly smaller grains with respect to R118 (Figures 12A,C and 12B,D) and R053 (Figures 4 (blue box) and 12A,C), in agreement with the trend in crystal size reported in Table S3. Interestingly, after thermal treatment at $1000^{\circ} \mathrm{C}$, the grain size increased only for R046, reaching approximately the same size of the grains of R118 sample, suggesting a strong agglomeration of crystallites for R118 calcined at $700{ }^{\circ} \mathrm{C}$. Therefore, the microstructural and morphological properties of 

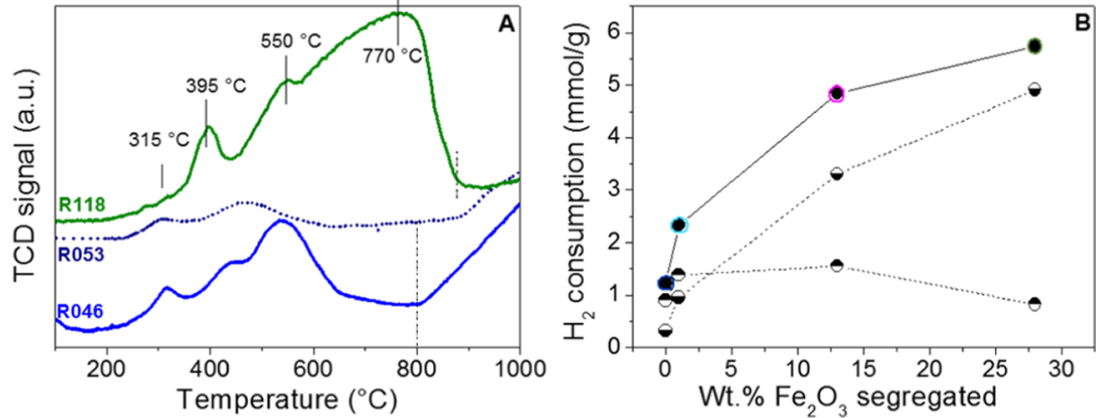

Figure 11. (A) TPR profiles of the single-phase waste-derived sample R053 in comparison with those of iron-poor (R046) and iron-rich (R118) representative samples. (B) $\mathrm{H}_{2}$ consumption at $T$ lower (black and white circles with black below) and higher (black and white circles with black above) than $800{ }^{\circ} \mathrm{C}$, and total $\mathrm{H}_{2}$ consumption $(\mathrm{mmol} / \mathrm{g})$ calculated from the integration of the TPR curves as a function of the segregated $\mathrm{Fe}_{2} \mathrm{O}_{3}$.

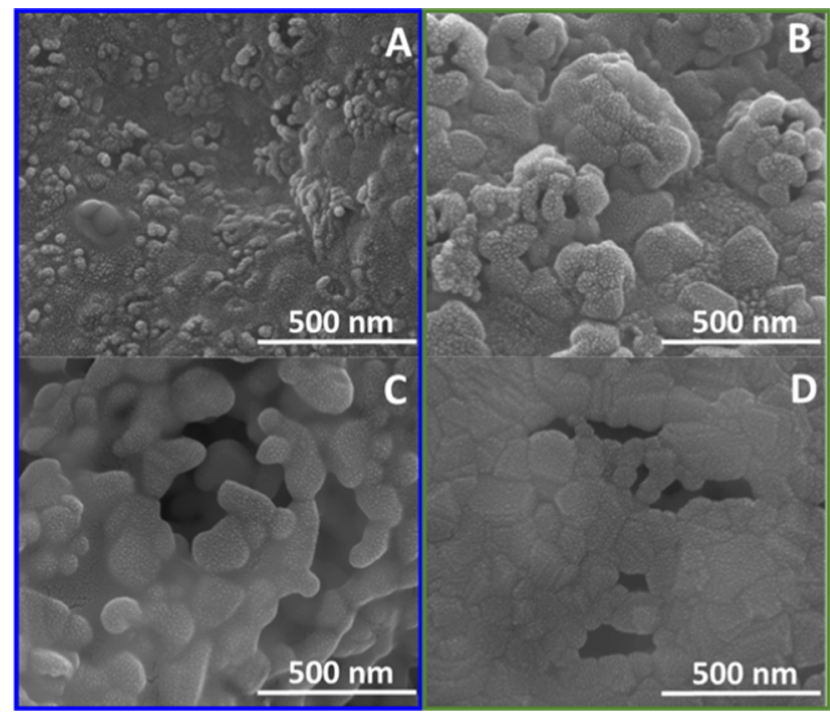

Figure 12. SEM images of iron-poor (electric blue box, A and C) and iron-rich (green box, $\mathrm{B}$ and $\mathrm{D}$ ) rust waste-derived powders, calcined at $700{ }^{\circ} \mathrm{C}(\mathrm{A}, \mathrm{B})$ and $1000{ }^{\circ} \mathrm{C}(\mathrm{C}, \mathrm{D})$.

$\mathrm{LaFeO}_{3}$ powders prepared from waste iron precursor were strongly influenced by the amount of waste iron.

Propylene conversion increased with the temperature for all of the investigated samples (Figure 13). The activity trend for $\mathrm{LaFeO}_{3}$ catalysts was found to be in the following order: R080 $\sim \mathrm{R} 118 \sim \mathrm{R} 054 \gg \mathrm{R} 046$ (Figure 13).

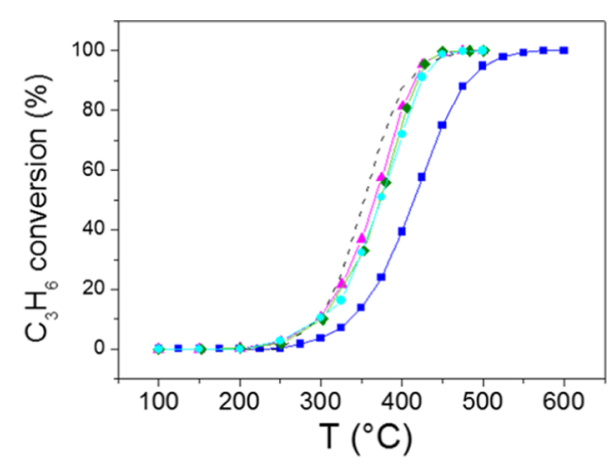

Figure 13. Conversion curves for the propylene oxidation on the rust waste-derived $\mathrm{LaFeO}_{3}$ samples: R046 (blue squares), R054 (cyan circles), R080 (magenta triangles), and R118 (green rhombs). FeNit reference sample is indicated by the black dashed line.
FeNit was also reported in Figure 13 as a reference. Its activity (as well as the activity of the single-phase R053 sample (Figure 6)) was almost comparable to that of the iron-rich samples, and all performed better than the iron-poor sample (Figure 13), displaying temperatures for 50 and $100 \%$ propylene conversions about $50{ }^{\circ} \mathrm{C}$ lower than those over R046. The relatively low temperatures at which propylene conversion occurred over the iron-rich samples suggests that the $\mathrm{Fe}_{2} \mathrm{O}_{3}$ detected as secondary phase can contribute to the catalytic activity. These results indicate that the proposed synthetic approach is quite successful even in the presence of consistent $\mathrm{Fe}_{2} \mathrm{O}_{3}$ impurities. On the other hand, the iron-poor sample (R046) was less active in the propylene oxidation. According to the work of Schön et al., ${ }^{23}$ the excess of $\mathrm{La}$ species on the surface of R046 might be highly responsible for the decreased activity of this sample with respect to the FeNit reference (Figure 13). Thinking of an industrial application, our results highlighted that an excess of waste iron could be always considered a better choice for obtaining optimized catalytic performance of $\mathrm{LaFeO}_{3}$-based catalysts, whereas a substoichiometric $\mathrm{Fe} / \mathrm{La}$ ratio would be deleterious. In addition, knowledge of the exact phase composition of the waste-derived iron precursor would not be strictly required under over-stoichiometric $\mathrm{Fe} / \mathrm{La}$ ratio. This overcomes any drawback connected with the intrinsic variability of rust waste and with the determination of the exact amount of iron precursor needed for obtaining a single-phase perovskite.

\section{CONCLUSIONS}

For the first time, an economical, widespread and available waste iron has been successfully recycled as an iron precursor to prepare a $\mathrm{LaFeO}_{3}$ perovskite by solution combustion-based methodologies. The iron-containing perovskite has been tested as a heterogeneous catalyst for propylene oxidation, closing the circle of this sustainable procedure.

On comparing with the commercial iron nitrate precursor, the waste iron is able to produce an iron perovskite with the same catalytic activity. In addition, the waste iron affects the microstructural properties of the perovskite powder, changing both particle size and shape.

Two main limitations of the effectiveness of this recycling procedure have been identified, which may introduce a variability factor into the final iron-containing perovskite powder composition: the intrinsic variability of the rust waste from scrap iron and the need to carefully determine the stoichiometric amount of rust waste by experimental evaluation. However, it has been found that these limitations 


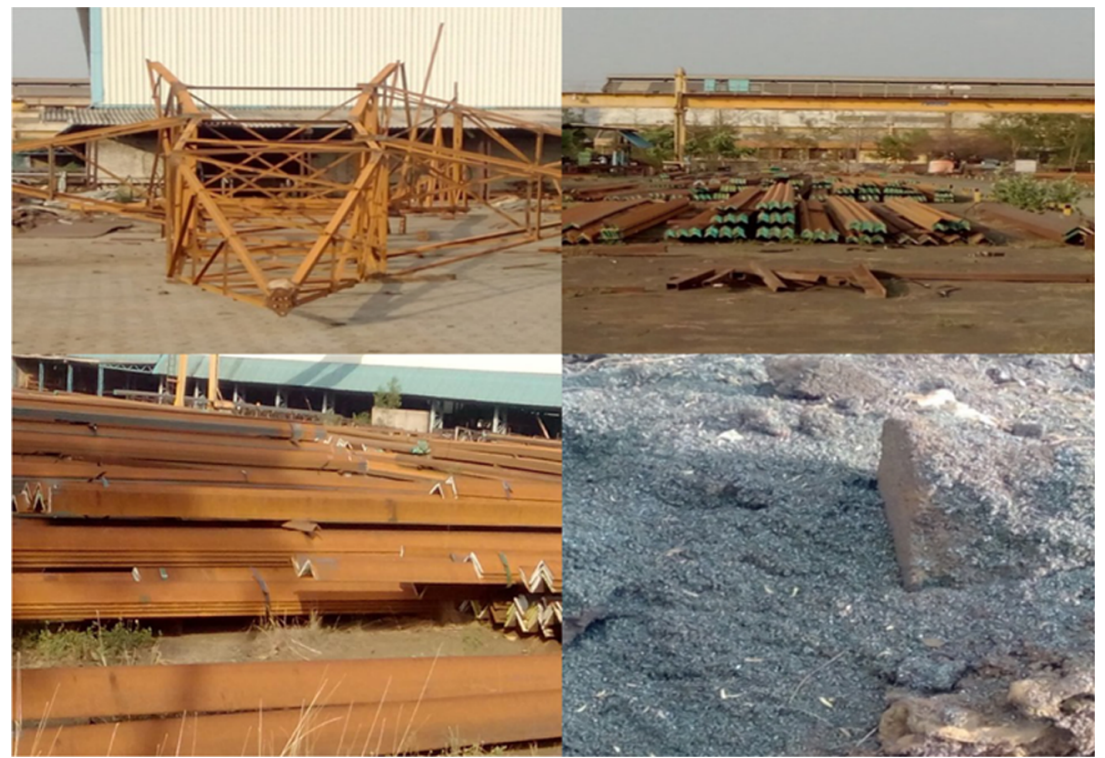

Figure 14. Rust waste produced from scraping of the rusted electricity transmission towers of a manufacturing industry close to Nagpur (India). All of the pictures were taken by the authors.

may be partially overcome by using an excess of rust waste since the activity of the iron-rich compositions does not change with the waste iron content in a reasonably wide range $(0.54-$ $1.18 \mathrm{~g})$.

The proposed approach can be easily extended to the preparation of doped $\mathrm{LaFeO}_{3}$ and other iron-containing compounds, enabling the sustainable production of a variety of functional materials. Above all, this work envisages the possibility to exploit insoluble waste inorganic precursors directly for the synthesis of nanomaterials, bypassing any time/ solvent/acid-consuming extraction step. In addition, our results encourage the application of this powerful methodology to other insoluble waste metal precursors for the synthesis of perovskite-type compounds with different compositions.

\section{EXPERIMENTAL SECTION}

Rust Waste Collection and Pretreatment. Rust waste was collected in powdered form from the transmission line tower manufacturing unit of an industry near Nagpur, India (Figure 14).

The as-received rust waste was washed in a stainless steel beaker with distilled water at about $90{ }^{\circ} \mathrm{C}$ for $1 \mathrm{~h}$ under manual stirring. Then, the water was taken out of the beaker and replaced with clean cold water. Washed rust waste was then dried overnight in an oven at $80{ }^{\circ} \mathrm{C}$. The obtained powder was magnetic and brown and was called "waste iron".

Synthesis of $\mathrm{LaFeO}_{3}$ Powders. The chemicals used for the synthesis of the waste-derived powders were $\mathrm{La}\left(\mathrm{NO}_{3}\right)_{3}$. $6 \mathrm{H}_{2} \mathrm{O}$ (Sigma-Aldrich, 99.999\%), $\mathrm{C}_{6} \mathrm{H}_{8} \mathrm{O}_{7}$ anhydrous (Alfa Aesar, >99.5\%), $\mathrm{NH}_{4} \mathrm{NO}_{3}$ (Sigma-Aldrich, 99.5\%), $\mathrm{NH}_{4} \mathrm{OH}$ (Sigma-Aldrich, water solution, $28 \% \mathrm{vol}$ ), and the waste iron obtained after the washing treatment. The reference sample was prepared by using the same type of chemicals except for the waste iron precursor, which was replaced by $\mathrm{Fe}\left(\mathrm{NO}_{3}\right)_{3}$. $9 \mathrm{H}_{2} \mathrm{O}$ (Alfa Aesar Puratronic, 99.999\%).

To prepare the waste-derived samples, lanthanum nitrate, citric acid, ammonium nitrate, and selected amounts of waste iron (Table 1) were weighed in required proportions and poured into a stainless steel beaker. Then, $400 \mathrm{~mL}$ of distilled
Table 1. Legend of the Samples According to the Amount of Waste Iron Precursor Used

\section{Sample $\quad \mathrm{g}$ of waste iron precursor used for each sample}

$\begin{array}{ll}\text { R046 } & 0.4600 \\ \text { R049 } & 0.4933 \\ \text { R051 } & 0.5121 \\ \text { R053 } & 0.5305 \\ \mathbb{R} 054 & 0.5412 \\ \mathbb{R} 065 & 0.6518 \\ \text { R080 } & 0.8020 \\ \mathbb{R} 118 & 1.1840\end{array}$

water was added and $\mathrm{pH}$ was regulated at 6 by adding ammonia solution. The stainless steel beaker containing all of the combustion ingredients was kept on a hot plate with the vertex set at $80{ }^{\circ} \mathrm{C}$, and the water was allowed to evaporate by mechanical stirring until a gel was formed. After gel formation, the vertex and the stirrer were removed and combustion was initiated by heating the gel mass up to about $200{ }^{\circ} \mathrm{C}$. The asburned powders produced after combustion were denoted by $R$ (" $R$ " = rust waste) followed by three numbers, indicating the amount of waste iron precursor used for the synthesis, without the dot and taking into account just the two decimal numbers (i.e., if waste iron is 0.5305 , then the name of the sample is R053) (Table 1). 

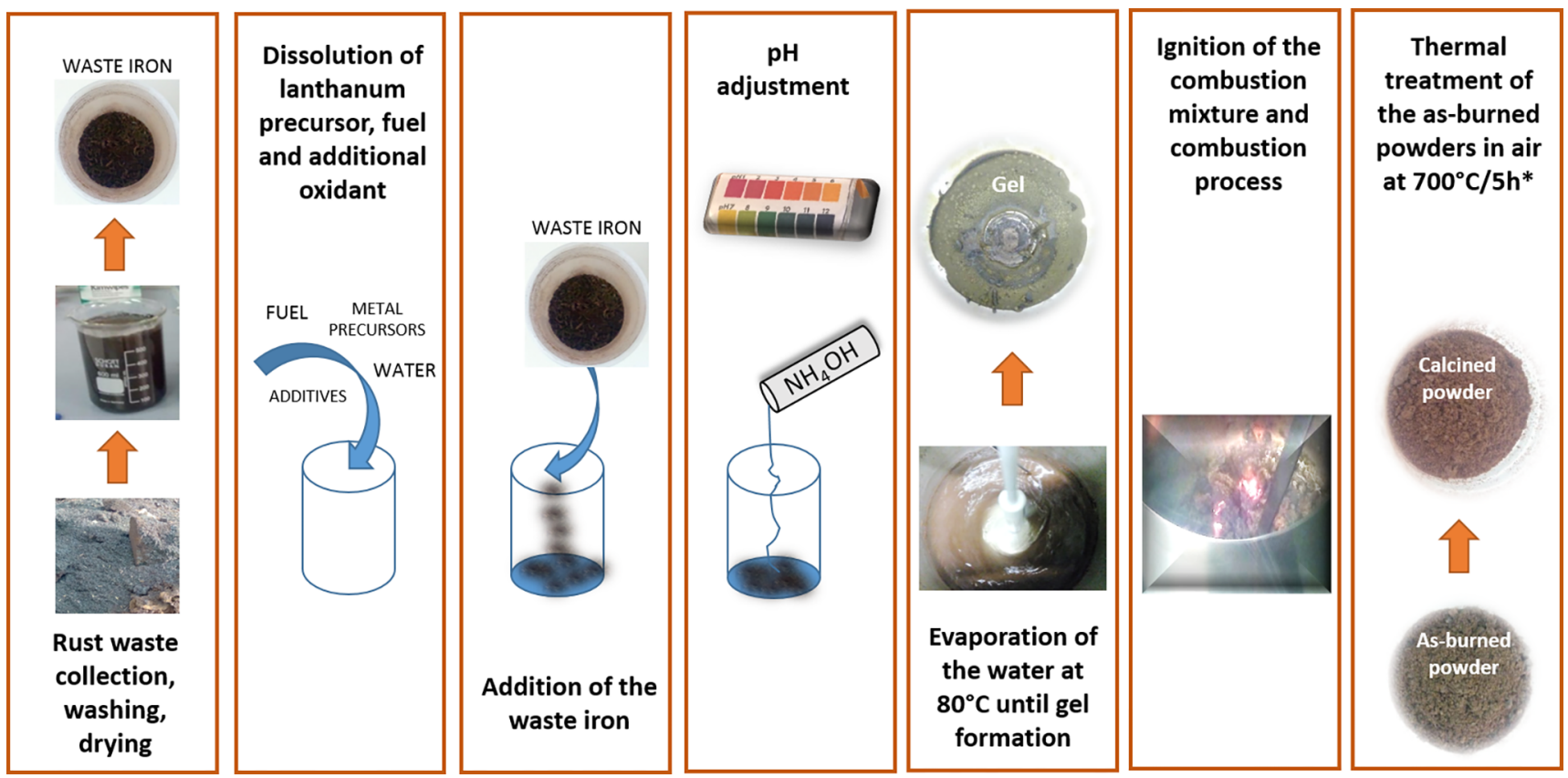

Figure 15. Scheme of the procedure adopted for the synthesis of rust-derived $\mathrm{LaFeO}_{3}$ powders. $(*)$ A further thermal treatment at $1000{ }^{\circ} \mathrm{C} / 5 \mathrm{~h}$ was also performed for characterization purposes. All of the pictures were taken by the authors.

For all of the samples, the amount of lanthanum precursor was fixed at $3.568 \mathrm{~g}$ of $\mathrm{La}\left(\mathrm{NO}_{3}\right)_{3} \cdot 6 \mathrm{H}_{2} \mathrm{O}$, corresponding to a batch of $2 \mathrm{~g}$ of perovskite powder with a $\mathrm{Fe} / \mathrm{La}$ molar ratio of 1. Lanthanum nitrate is both a La source and a $\mathrm{NO}_{3}{ }^{-}$oxidant source. During the combustion process, lanthanum nitrate was transformed into $\mathrm{LaFeO}_{3}$, whereas $\mathrm{NO}_{3}{ }^{-}$was reduced by citric acid (fuel) through a self-sustained redox reaction.

The citric acid-to-lanthanum molar ratio was fixed to 1 , whereas the fuel-to-metal cations ratio (metal cations $=\mathrm{La}+$ $\mathrm{Fe}$ ) oscillated between 1.24 and 2.14 , depending on the iron content.

The amount of waste iron precursor was varied according to Table 1, producing powders with different total $\mathrm{Fe} / \mathrm{La}$ molar ratios. The purpose of this study was to obtain the exact waste iron precursor amount needed for a pure sample and to check the properties and performance of the samples in the common case where the amount of the stoichiometric waste ion precursor is not exactly known. The iron content in the rust waste-derived samples was calculated "a posteriori" according to a procedure described in the Supporting Information ( $p$ S17).

The reducers-to-oxidizers ratio $(\Phi)$ was set at 1.9 by using a selected amount of ammonium nitrate as additional oxidant, according to the propellant chemistry calculations. ${ }^{20}$ The amount of $\mathrm{NH}_{4} \mathrm{NO}_{3}$ oxidant was the same for all of the wastederived samples, disregarding the amount of waste iron used because it was calculated with respect to the amount of citric acid and the amount of $\mathrm{NO}_{3}{ }^{-}$counterion in the lanthanum precursor.

Over-stoichiometric $\Phi$ values were chosen for safety reasons in view of an industrial application, where due to the higher amount of powder produced in a single batch, attenuated combustion is preferable. ${ }^{20}$

An identical procedure was used for the preparation of the reference sample, although commercial $\mathrm{Fe}\left(\mathrm{NO}_{3}\right)_{3} \cdot 9 \mathrm{H}_{2} \mathrm{O}$ (FeNit, where Nit stands for "nitrate") was used as iron precursor. The amount of $\mathrm{Fe}\left(\mathrm{NO}_{3}\right)_{3} \cdot 9 \mathrm{H}_{2} \mathrm{O}$ weighed for preparing the FeNit sample, with a stoichiometric $\mathrm{Fe} / \mathrm{La}$, was $3.3284 \mathrm{~g}$, which corresponded to the same molar amount of $\mathrm{La}\left(\mathrm{NO}_{3}\right)_{3} \cdot 6 \mathrm{H}_{2} \mathrm{O}$. Due to the presence of $\mathrm{NO}_{3}{ }^{-}$counter anions in the commercial iron precursor, the amount of additional oxidant was lowered to maintain the $\Phi$ ratio at 1.9.

All of the as-burned powders were then kept in the furnace in an alumina crucible for calcination in static air at $700{ }^{\circ} \mathrm{C}$ for $5 \mathrm{~h}\left(10^{\circ} \mathrm{C} / \mathrm{min}\right)$ to get the final material. For characterization purposes, a portion of the powder was further treated at 1000 ${ }^{\circ} \mathrm{C}$ for another $5 \mathrm{~h}$ to allow complete crystallization of all of the phases. The samples calcined at $1000{ }^{\circ} \mathrm{C}$ were called with the original sample name followed by “_1000”. In Figure 15, the steps of the synthesis procedure used are illustrated.

Characterization Techniques. Powder X-ray diffraction (PXRD) patterns were taken on the waste iron, as-burned samples, and calcined samples $\left(700{ }^{\circ} \mathrm{C} / 5 \mathrm{~h}\right.$ and $\left.1000{ }^{\circ} \mathrm{C} / 5 \mathrm{~h}\right)$ using a Bruker-Siemens D5000 X-ray powder diffractometer equipped with a Kristalloflex $760 \mathrm{X}$-ray generator and a curved graphite monochromator using $\mathrm{Cu} \mathrm{K} \alpha$ radiation $(40 \mathrm{kV} / 30$ $\mathrm{mA}$ ). The $2 \theta$ step size was $0.03^{\circ}$, the integration time was $3 \mathrm{~s}$ per step, and the $2 \theta$ scan ranged from 10 to $90^{\circ}$. Diffraction patterns were compared with ICSD Database ${ }^{33}$ and analyzed by Rietveld refinement using the GSAS package. ${ }^{34,35}$

Fourier transform infrared (FT-IR) spectroscopy measurements were made with a Thermo Nicolet, Avatar 370 instrument in the $4000-400 \mathrm{~cm}^{-1}$ spectral range, with a resolution of $4 \mathrm{~cm}^{-1}$, using a $\mathrm{KBr}$ beam splitter, DTGS Detector, and an HATR assembly for convenience of measurement. Signal identification was done with the help of a database for the identification of unknown compounds. About $2 \mathrm{mg}$ of solid sample was used.

X-ray photoelectron spectroscopy (XPS) analyses were performed with a VGMicrotech ESCA 3000Multilab, equipped with a dual $\mathrm{Mg} / \mathrm{Al}$ anode. The spectra were excited by the unmonochromatized $\mathrm{Al} \mathrm{K} \alpha$ source $(1486.6 \mathrm{eV}$ ) run at $14 \mathrm{kV}$ and $15 \mathrm{~mA}$. The analyzer was operated in the constant analyzer energy mode. For the individual peak energy regions, a pass 
energy of $20 \mathrm{eV}$ set across the hemispheres was used. The pressure in the analysis chamber was in the range of $10^{-8}$ Torr during data collection. The constant charging of the samples was removed by referencing all of the energies to $L a 3 d_{5 / 2}$ at $842.1 \mathrm{eV}$, as internal standard. Analyses of the peaks were performed with the software CasaXPS. Atomic concentrations were calculated from peak intensity using the sensitivity factors provided with the software. The binding energy values are quoted with a precision of $\pm 0.15 \mathrm{eV}$, and the atomic percentage with a precision of $\pm 10 \%$.

The surface microstructure and morphology of $\mathrm{LaFeO}_{3}$ nanopowders was examined by scanning electron microscopy (SEM), using an FEI Quanta 200 ESEM microscope, operating at $20 \mathrm{kV}$ on specimens upon which a thin layer of gold had been evaporated. Energy-dispersive X-ray (EDX) analyses were also performed during the SEM observation.

Elemental analysis was performed by microwave plasma atomic emission spectroscopy (MP-AES). The samples (ca. 30 $\mathrm{mg}$ ) were dissolved in $2 \mathrm{~mL}$ of aqua regia and diluted to $10 \mathrm{~mL}$ with distilled water. The analyses were made with an Agilent 4200 MP-AES.

Specific surface area (the Brunauer-Emmett-Teller method) ${ }^{36}$ and pore size distributions (the Barrett-JoynerHalenda method) ${ }^{37}$ were evaluated by nitrogen adsorption/ desorption measurements at $-196{ }^{\circ} \mathrm{C}$, using ASAP 2020 Plus Materials. All of the samples were pretreated under vacuum at $250{ }^{\circ} \mathrm{C}$ for $2 \mathrm{~h}$ prior to the measurements.

Reduction properties of the samples were studied by temperature-programmed reduction (TPR) experiments by flowing $\mathrm{H}_{2} / \mathrm{Ar}(5 \%, 30 \mathrm{~mL} / \mathrm{min})$ and increasing the temperature between 25 and $1020{ }^{\circ} \mathrm{C}$ (heating rate, $10{ }^{\circ} \mathrm{C} / \mathrm{min}$ ). Experiments were carried out with a Micromeritics Autochem 2910 instrument equipped with a thermal conductivity detector (TCD). All powders $(\sim 0.1 \mathrm{~g})$ were pretreated in $\mathrm{O}_{2} / \mathrm{He}(5 \%, 30 \mathrm{~mL} / \mathrm{min})$ at $350{ }^{\circ} \mathrm{C}$ for $30 \mathrm{~min}$ and then cooled down under $\mathrm{He}(30 \mathrm{~mL} / \mathrm{min})$, before starting TPR. The hydrogen consumption was evaluated by integration of the reduction peaks and applying a calibration curve. The values in terms of mmol of $\mathrm{H}_{2}$ consumed per gram of sample are quoted with a precision of $\pm 5 \%$. To avoid any interference in the hydrogen consumption evaluation by using TCD analyzer, the water formed during the reduction process was removed from the gas stream using a cold trap.

Activity tests for the propylene oxidation were carried out in a U-shaped quartz reactor operating under continuous flow at atmospheric pressure. The reactor temperature was measured by a thermocouple placed coaxially inside the reactor. The feeding was a gas mixture $(50 \mathrm{~mL} / \mathrm{min})$ having $2500 \mathrm{ppm}$ of propylene and $15 \% \mathrm{O}_{2}$ (balance $\mathrm{He}$ ). Powder $(50 \mathrm{mg}$ ) was used for each run corresponding to a weight hourly space velocity of $60000 \mathrm{~mL} /(\mathrm{gh})$. Before the catalytic experiments, the powder was manually crushed in an agate mortar to achieve the same level of granulometry. The activity tests were carried out in the $100-500{ }^{\circ} \mathrm{C}$ range with steps of $25^{\circ} \mathrm{C}$ and waiting $30 \mathrm{~min}$ for each step to get steady-state conditions. The feed and the effluent gases were analyzed using UV-IR $\mathrm{ABB}$ Analyzers to detect $\mathrm{CO}$ and $\mathrm{CO}_{2}$ and a paramagnetic analyzer for $\mathrm{O}_{2}$. The propylene conversion was evaluated based on the detected $\mathrm{CO}$ and $\mathrm{CO}_{2}$.

\section{ASSOCIATED CONTENT}

\section{S Supporting Information}

The Supporting Information is available free of charge on the ACS Publications website at DOI: 10.1021/acsomega.8b03522.

FT-IR spectra, XPS survey, Fe2p and O1s XPS spectra of rust waste; temperature/time profiles registered during the combustion process; morphological properties, redox properties, structural parameters, binding energies, surface area and pore volume of selected rust waste-derived samples and of the reference FeNit sample; procedure for the determination of the stoichiometric amount of waste iron (PDF)

\section{AUTHOR INFORMATION}

\section{Corresponding Author}

*E-mail: francesca.deganello@cnr.it. Tel: +39 0916809387. Fax: +39 0916809399 .

\section{ORCID ${ }^{\circ}$}

Francesca Deganello: 0000-0002-9194-9742

Manisha Joshi: 0000-0003-4168-3330

Leonarda F. Liotta: 0000-0001-5442-2469

Valeria La Parola: 0000-0001-7695-6031

Giuseppe Marcì: 0000-0003-2215-6543

Giuseppe Pantaleo: 0000-0002-2474-8481

\section{Author Contributions}

The manuscript was written through contributions of all authors. All authors have given approval to the final version of the manuscript.

\section{Notes}

The authors declare no competing financial interest.

\section{ACKNOWLEDGMENTS}

The authors thank Francesco Giordano for performing the XRD measurements. STM2016 mobility program (CNR Contract, AMMCNT-CNR no. 73311 of $03 / 11 / 2016$ ) is greatly acknowledged for financial resources.

\section{REFERENCES}

(1) Das, N.; Kandimalla, S. Application of perovskites towards remediation of environmental pollutants: an overview. Int. J. Environ. Sci. Technol. 2017, 14, 1559-1572.

(2) García-López, E.; Marcì, G.; Puleo, F.; La Parola, V.; Liotta, L. F. $\mathrm{La}_{1-\mathrm{x}} \mathrm{Sr}_{\mathrm{x}} \mathrm{Co}_{1-\mathrm{y}} \mathrm{Fe}_{\mathrm{y}} \mathrm{O}_{3-\delta}$ perovskites: Preparation, characterization and solar photocatalytic activity. Appl. Catal., B 2015, 178, 218-225.

(3) Liotta, L. F.; Puleo, F.; La Parola, V.; Leonardi, S. G.; Donato, N.; Aloisio, D.; Neri, G. $\mathrm{La}_{0.6} \mathrm{Sr}_{0.4} \mathrm{FeO}_{3-\delta}$ and $\mathrm{La}_{0.6} \mathrm{Sr}_{0.4} \mathrm{Co}_{0.2} \mathrm{Fe}_{0.8} \mathrm{O}_{3-\delta}$ Perovskite Materials for $\mathrm{H}_{2} \mathrm{O}_{2}$ and Glucose Electrochemical Sensors. Electroanalysis 2015, 27, 684-692.

(4) Sunarso, J.; Hashim, S. S.; Zhu, N.; Zhou, W. Perovskite oxides applications in high temperature oxygen separation, solid oxide fuel cell and membrane reactor: A review. Prog. Energy Combust. Sci. 2017, $61,57-77$.

(5) Hwang, J.; Rao, R. R.; Giordano, L.; Katayama, Y.; Yu, Y.; ShaoHorn, Y. Perovskites in catalysis and electrocatalysis. Science 2017, $358,751-756$.

(6) European Commission. A Clean Planet for all. A European strategic long-term vision for a prosperous, modern, competitive and climate neutral economy, Communication from the commission to the European parliament, the European council, the council, the European economic and social committee, the committee of the regions and the European investment bank, $\operatorname{COM}(2018) 773$ : Brussels, Nov 28, 2018. 
(7) Li, X.; Wang, C.; Zeng, Y.; Li, P.; Xie, T.; Zhang, Y. Bacteriaassisted preparation of nano $\alpha-\mathrm{Fe}_{2} \mathrm{O}_{3}$ red pigment powders from waste ferrous sulfate. J. Hazard. Mater. 2016, 317, 563-569.

(8) Novoselova, L. Y. Hematite nanopowder obtained from waste: Iron-removal sludge. Powder Technol. 2016, 287, 364-372.

(9) Rodrigues Fiuza, T. E.; Borges, J. F. M.; Marimon da Cunha, J. B.; Masetto Antunes, S. R.; Chaves de Andrade, A. V.; Celso Antunes, A.; Ferreira de Souza, E. C. Iron-based inorganic pigments from residue: Preparation and application in ceramic, polymer, and paint. Dyes Pigm. 2018, 148, 319-328.

(10) Wang, J.; Li, L.; Lei, Y.; Zhang, Y.; Li, P.; Zhu, C.; Wang, K.; Zheng, Z.; Yang, X. Facile Chemical Solution Transportation for Direct Recycling of Iron Oxide Rust Waste to Hematite Films. ACS Sustainable Chem. Eng. 2018, 6, 12232-12240.

(11) Pullar, R. C.; Saeli, M.; Novais, R. M.; Amaral, J. S.; Labrincha, $\mathrm{J}$. A. Valorisation of industrial iron oxide waste to produce magnetic barium hexaferrite. ChemistrySelect 2016, 1, 819-825.

(12) Dufour, J.; Latorre, R.; Negro, C.; Alcalá, E. M.; Formoso, A.; López-Mateos, F. Protocol for the synthesis of Ba-hexaferrites with prefixed coercivities. J. Magn. Magn. Mater. 1997, 172, 308-316.

(13) Babar, S.; Gavade, N.; Shinde, H.; Mahajan, P.; Lee, K. H.; Mane, N.; Deshmukh, A.; Garadkar, K.; Bhuse, V. Evolution of Waste Iron Rust into Magnetically Separable g- $\mathrm{C}_{3} \mathrm{~N}_{4}-\mathrm{Fe}_{2} \mathrm{O}_{3}$ Photocatalyst: An Efficient and Economical Waste Management Approach. ACS Appl. Nano Mater. 2018, 1, 4682-4694.

(14) Mhamane, D.; Roh, K. C.; Kim, H.-K.; Srinivasan, M.; Aravindan, V.; Kim, K.-B. Rusted iron wire waste into high performance anode $\left(\alpha-\mathrm{Fe}_{2} \mathrm{O}_{3}\right)$ for Li-ion batteries: an efficient waste management approach. Green Chem. 2016, 18, 1395-1404.

(15) Adegoke, J. A.; Halimat, I. A. Absorption Studies of Arsenic Using Maghemite Crystals Synthesized from Iron Waste Extracted from Ogun State Iron Mill Dumpsite. Am. J. Anal. Chem. 2016, 7, 294-298.

(16) Deganello, F.; Tummino, M. L.; Calabrese, C.; Testa, M. L.; Avetta, P.; Fabbri, D.; Bianco Prevot, A.; Montoneri, E.; Magnacca, G. A new, sustainable $\mathrm{LaFeO}_{3}$ material prepared from biowaste-sourced soluble substances. New J. Chem. 2015, 39, 877-885.

(17) Taylor, F. H.; Buckeridge, J.; Catlow, C. R. A. Defects and Oxide Ion Migration in the Solid Oxide Fuel Cell Cathode Material $\mathrm{LaFeO}_{3}$. Chem. Mater. 2016, 28, 8210-8220.

(18) Roseno, K. T. C.; Brackmann, R.; da Silva, M. A.; Schmal, M. Investigation of $\mathrm{LaCoO}_{3}, \mathrm{LaFeO}_{3}$ and $\mathrm{LaCo}_{0.5} \mathrm{Fe}_{0.5} \mathrm{O}_{3}$ perovskites as catalyst precursors for syngas production by partial oxidation of methane. Int. J. Hydrogen Energy 2016, 41, 18178-18192.

(19) Zhao, S.; Wang, L.; Wang, Y.; Li, X. Hierarchically porous $\mathrm{LaFeO}_{3}$ perovskite prepared from the pomelo peel bio-template for catalytic oxidation of NO. J. Phys. Chem. Solids 2018, 116, 43-49.

(20) Deganello, F.; Tyagi, A. K. Solution combustion synthesis, energy and environment: Best parameters for better materials. Prog. Cryst. Growth Charact. Mater. 2018, 64, 23-61.

(21) Zhu, J.; Li, L.; Xiong, Z.; Hu, Y.; Jiang, J. Evolution of Useless Iron Rust into Uniform $\alpha-\mathrm{Fe}_{2} \mathrm{O}_{3}$ Nanospheres: A Smart Way to Make Sustainable Anodes for Hybrid Ni-Fe Cell Devices. ACS Sustainable Chem. Eng. 2017, 5, 269-276.

(22) Huang, H.; Xu, Y.; Feng, Q.; Leung, D. Y. C. Low temperature catalytic oxidation of volatile organic compounds: a review. Catal. Sci. Technol. 2015, 5, 2649-2669.

(23) Schön, A.; Dacquin, J.-P.; Granger, P.; Dujardin, C. Non stoichiometric $\mathrm{La}_{1-\mathrm{y}} \mathrm{FeO}_{3}$ perovskite-based catalysts as alternative to commercial three-way-catalysts? - Impact of $\mathrm{Cu}$ and $\mathrm{Rh}$ doping. Appl. Catal., B 2018, 223, 167-176.

(24) Balasubramaniam, R.; Ramesh Kumar, A. V.; Dillmann, P. Characterization of rust on ancient Indian iron. Curr. Sci. 2003, 85, $1546-1555$.

(25) Deganello, F.; Testa, M. L.; La Parola, V.; Longo, A.; Tavares, A. $\mathrm{LaFeO}_{3}$-based nanopowders prepared by a soft-hard templating approach: the effect of silica texture. J. Mater. Chem. A 2014, 2, 84388447.
(26) Barbero, B. P.; Gamboa, J. A.; Cadùs, L. E. Synthesis and characterization of $\mathrm{La}_{1-\mathrm{x}} \mathrm{Ca}_{\mathrm{x}} \mathrm{FeO}_{3}$ perovskite-type oxide catalysts for total oxidation of volatile organic compounds. Appl. Catal., B 2006, $65,21-30$.

(27) Gregg, S. J.; Singh, K. S. W. Absorption, Surface Area and Porosity, Academic Press, 1982.

(28) Sunding, M. F.; Hadidi, K.; Diplas, S.; Løvvik, O. M.; Norby, T. E.; Gunnæs, A. E. XPS characterization of in situ treated lanthanum oxide and hydroxide using tailored charge referencing and peak fitting procedures. J. Electron Spectrosc. Relat. Phenom. 2011, 184, 399-409.

(29) Faye, J.; Guelou, E.; Barrault, J.; Tatibouet, J. M.; Valange, S. $\mathrm{LaFeO}_{3}$ Perovskite as New and Performant Catalyst for the Wet Peroxide Oxidation of Organic Pollutants in Ambient Conditions. Top. Catal. 2009, 52, 1211-1219.

(30) Medkhali, A. H. A.; Narasimharao, K.; Basahel, S. N.; Mokhtar, M. Divalent Transition Metals Substituted $\mathrm{LaFeO}_{3}$ Perovskite Catalyst for Nitrous Oxide Decomposition. J. Membr. Sep. Technol. 2014, 3, 206-212.

(31) Chrétien, S.; Metiu, H. Hydrogen Dissociative Adsorption on Lanthana: Polaron Formation and the Role of Acid-Base Interactions. J. Phys. Chem. C 2015, 119, 19876-19882.

(32) Cho, Y.-G.; Choi, K.-H.; Kim, Y.-R.; Jung, J.-S.; Lee, S.-H. Characterization and Catalytic Properties of Surface La-rich $\mathrm{LaFeO}_{3}$ Perovskite. Bull. Korean Chem. Soc. 2009, 30, 1368-1372.

(33) Bergerhoff, G.; Brown, I. D. In Crystallographic Databases; Allen, F. H. et al., Ed.; International Union of Crystallography: (Hrsg.) Chester, 1987.

(34) Larson, A. C.; Von Dreele, R. B. General Structure Analysis System (GSAS), Los Alamos National Laboratory Report LAUR 2000, 2000; pp 86-748.

(35) Toby, B. H. EXPGUI, a graphical user interface for GSAS. J. Appl. Crystallogr. 2001, 34, 210-213.

(36) Brunauer, S.; Emmett, P. H.; Teller, E. Adsorption of gases in multimolecular layer. J. Am. Chem. Soc. 1938, 60, 309-319.

(37) Barrett, E. P.; Joyner, L. G.; Halenda, P. P. The Determination of Pore Volume and Area Distributions in Porous Substances. I. Computations from Nitrogen Isotherms. J. Am. Chem. Soc. 1951, 73, $373-380$. 